\title{
Prehistoric Hunting Strategies in New Ireland, Papua New Guinea: The Evidence of the Cuscus (Phalanger orientalis) Remains from Buang Merabak Cave
}

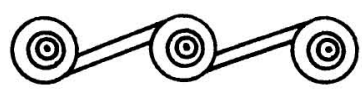

\author{
MATTHEW G. LEAVESLEY
}

RECENT HUNTER-GATHERER STUdies in Island Southeast Asia and Melanesia have highlighted the nature and importance of arboreal plant and animal resource exploitation and management. Latinis (1999, 2000) has emphasized the importance of botanical resources and suggested that archaeofauna, as a reflection of hunting, may also provide important information about arboreal resource management. This research investigates the human exploitation of one particular prey species, the cuscus Phalanger orientalis in New Ireland, Papua New Guinea. Mortality profile data are used to investigate whether prehistoric hunters selectively captured any particular subset of the $P$. orientalis population, and the implications for hunting behavior are discussed.

Pleistocene hunter-gatherers in the Bismarck Archipelago (Fig. 1) had a broad diet: carbohydrate was obtained by a strategy of arboriculture (Gosden 1995), while protein was derived from hunting and gathering primarily coastal but also inland faunal resources (Allen et al. 1989; Gosden and Robertson 1991; Marshall and Allen 1991). The earliest evidence indicates that protein was procured from reef fish, shellfish, and scale fish and supplemented by the relatively impoverished island-based fauna including rats, bats, birds, and reptiles. Terrestrial fauna was important because it contributed protein and fat that were difficult to obtain from marine resources (Davidson and Leach $2001: 118)$. Since the human colonization of New Ireland, a number of land-based taxa were introduced, including the cuscus ( $P$. orientalis), the northern pademelon (Thylogale browni), the large spiny rat (Rattus praetor), the pig (Sus scrofa), the dog (Canis familiaris), and the chicken (Gallus gallus) (Flannery and White 1991; Grayson 2001; Heinsohn 2001). However, P. orientalis (Fig. 2) was the only taxon that was introduced during the Pleistocene, са. 20,000 в.P. ${ }^{1}$ After its introduction, archaeological remains of $P$. orientalis exist in relatively large quantities, indicating its importance to pre-

Matthew G. Leavesley, Leverhulme Centre for Human Evolutionary Studies, University of Cambridge. 


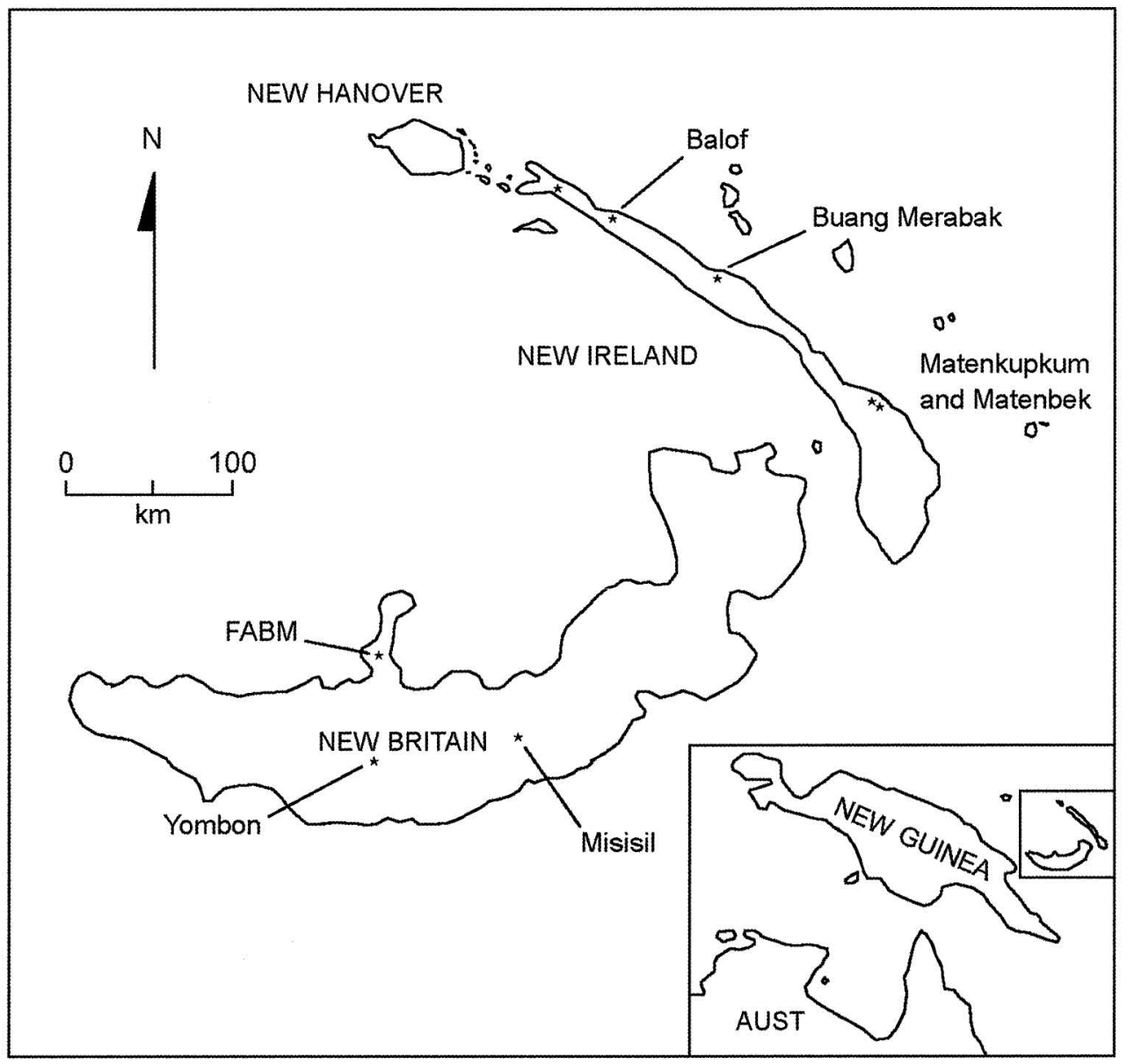

Fig. 1. Partial map of the Bismarck Archipelago indicating the Pleistocene archaeological sites.

historic hunters (Leavesley and Allen 1998:75) and in the ethnographic present (Latinis 1996, 1999; Sillitoe 2003:153-193).

$P$. orientalis is a Phalangerid possum with a wide distribution centered on the lowland forests of northern New Guinea and its satellite islands. While the Aru Islands were connected to New Guinea during periods of reduced sea level, neither New Britain nor New Ireland were ever connected to each other or to New Guinea. This led to the suggestion that $P$. orientalis was introduced by humans (Flannery and White 1991) through a process defined by Heinsohn (2003) as ethnophoresy.

$P$. orientalis has a gray to brown pelage coloration, prominent ears, slightly pointed face, and a naked prehensile tail (Fig. 2). Adults typically grow to about $2-3.5 \mathrm{~kg}$ in weight (Heinsohn 1998:82). They are not seasonal breeders (Flannery $1993: 175 ; 1995: 99)$ and often bear twin pouch young (Flannery and White 1991). They have a 12-month breeding cycle that finishes with the young moving to the back of the mother for approximately one month before asserting their 


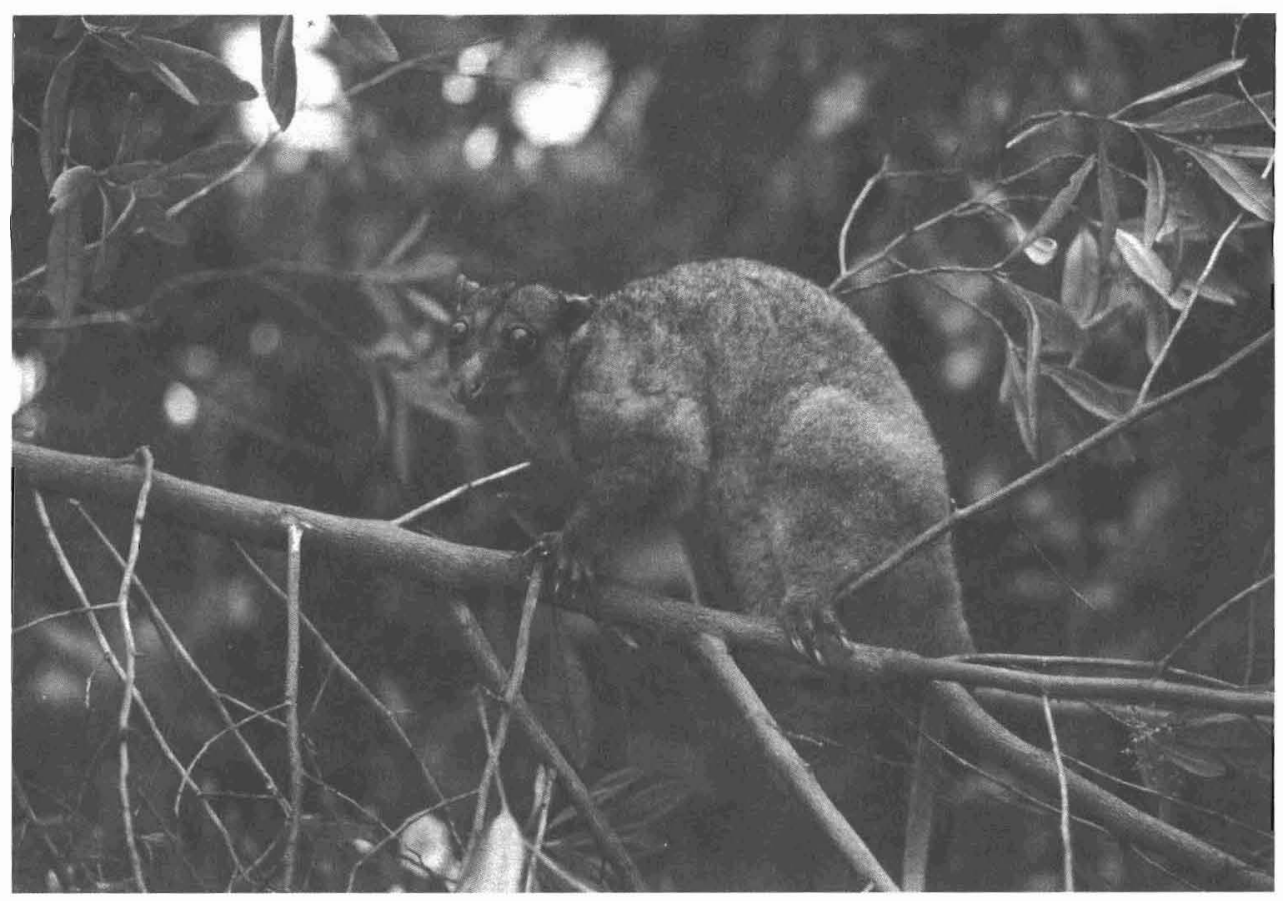

Fig. 2. Adult female cuscus (Phalanger orientalis) in New Ireland. (Photograph: Tom Heinsohn)

independence. They are nocturnal folivores/insectivores with a generalist diet consisting of leaves, fruit, and the occasional insect (Flannery 1993:175). Contemporary populations are arboreal and usually rainforest-dwelling, though they may also be found in the lower oak forest (van Deusen 1972:151). P. orientalis rarely leave the rainforest (Archer 1984:705), although in New Ireland they are known to inhabit strand forest, coconut plantation, and the edges of mangroves, as well as interior swamp forests. Cuscus were found to sleep in strand trees such as Barringtonia asiatica and Calophyllum inophyllum that overhang the beach and the sea at high tide (Heinsohn 1998). They sleep sometimes on exposed branches, and display occasional bouts of diurnal activity (Heinsohn $2000: 245$ ). The $P$. orientalis archaeofaunal assemblage described below was excavated from the Buang Merabak cave site.

Buang Merabak is located in central New Ireland, at the base of a series of limestone terraces that rise $\mathrm{ca} .1000 \mathrm{~m}$ to the Lelet Plateau. The cave consists of three chambers, the first extending $30 \mathrm{~m}$ into the hillside before narrowing to a squeeze that opens into a second chamber, a collapsed doline. The mouth of the cave faces north-northwest and is $15 \mathrm{~m}$ wide and $8 \mathrm{~m}$ high. The present study is based on faunal remains excavated from a test pit (TPIA and TPIB) located in the middle of the cave entrance several meters inside the mouth of the cave, behind the dripline. The test pit was excavated in $5 \mathrm{~cm}$ spits, the sediments being sieved through $3 \mathrm{~mm}$ mesh, with additional bulk sediment samples collected for laboratory analysis.

The Buang Merabak deposit was divided into four units differentiated by stra- 
tigraphy, chronology, and other site formation data (Leavesley 2004; Leavesley and Allen 1998). Unit 4 represented the initial occupation of the site and the period from ca. 39,500 в.P. (Leavesley et al. 2002) to ca. 28,000 в.P. A hiatus in deposit occurred between ca. 28,000 B.P. and ca. 20,000 B.P. Unit 3, representing the period from ca. 20,000 B.P. to ca. 17,000 B.P., contained the first evidence of P. orientalis. A second hiatus occurred from ca. 17,000 в.P. to ca. 12,000 в.P. Unit 2, representing the period from ca. 12,000 to ca. 7000 B.P., was followed by a third hiatus. Unit 1 represented the period from ca. 3500 to ca. 1800 B.P. (Leavesley 2004). The data and their interpretation are presented below in the context of these chronological units.

\section{METHODOLOGY}

The $P$. orientalis bones were excavated from a matrix of midden shell and stone artifacts, none of which was likely to have been deposited in the cave by natural formation processes, and the $P$. orientalis remains are considered to represent food refuse (Rosenfeld 1997). The assemblage was analyzed by classifying the teeth, whether in mandibles, maxilla, or as isolates, on the basis of eruption and tooth crown wear. Tooth eruption and wear increase with age, and can be considered as a proxy for animal age. They also have the advantage over other methods of age determination of being particularly accurate. The level of tooth wear can often be interpreted to give the age of an animal to within a year (Winter 1980). It is also little affected by the bone fragmentation that is such a common feature of faunal assemblages from archaeological sites.

$P$. orientalis has four upper molars, a relatively large premolar $3\left(\mathrm{P}^{3}\right)$, a canine (C), and three incisors $\left(\mathrm{I}^{1}\right.$ to $\left.\mathrm{I}^{3}\right)$ in each side of the maxilla (Archer 1984:706; Flannery $1995: 440$ ). They also have four lower molars, a relatively large premolar $\left(\mathrm{P}_{3}\right)$, the occasional deciduous premolars 1 and $2\left(\mathrm{P}_{1}\right.$ and $\left.\mathrm{P}_{2}\right)$, and at least one and sometimes two incisors $\left(\mathrm{I}_{1}\right.$ and $\mathrm{I}_{2}$ ?) in each side of the mandible (Archer 1984:706; Flannery 1995:440). The teeth scored for the purposes of this analysis were the four molars and the third premolar from both the maxilla and mandible. These generally erupt in the same order throughout all individuals within the species: the most anterior of the molars erupts first, followed sequentially through to the fourth molar.

When a tooth has fully erupted, the enamel is fully exposed above the alveola, whereas a tooth that is not fully erupted is sited lower in the alveola and is partly obscured. If a tooth is lost post-mortem, the alveola can still be classed in terms of its position in the eruption sequence: during the process of eruption the alveola changes shape as the jaw extends and the teeth move into position, so if the animal dies prior to the completion of the tooth eruption process and the teeth leave the alveola post-mortem, the alveola will still exhibit a form indicating that the teeth had not fully erupted. Hence a Buang Merabak mandible or maxilla could be classed under the eruption criteria with or without the presence of a tooth in the alveola.

Following tooth eruption, and as part of the natural process of mastication, the crowns of opposing teeth rub on each other, producing wear marks on their opposing enamel surfaces. Over time, the tooth enamel sustains wear that eventu- 


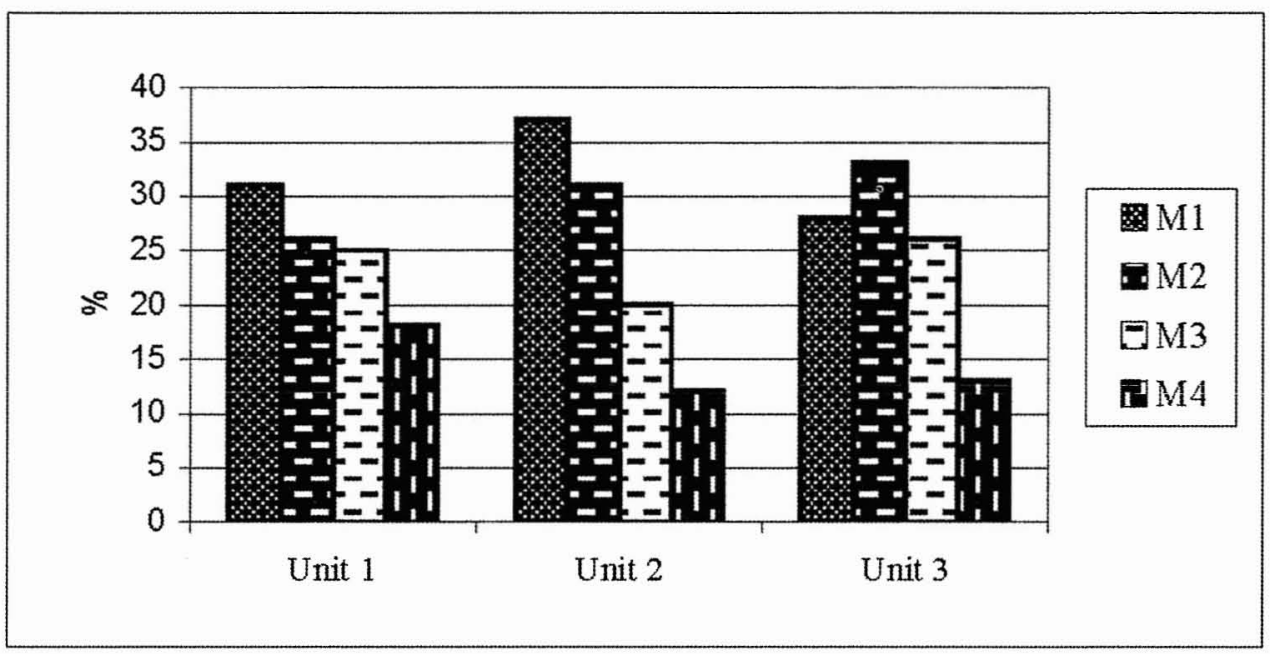

Fig. 3. Buang Merabak cuscus (Phalanger orientalis): the percentage of each molar per unit. Unit 1: 1800-3500 B.P.; Unit 2: 12,000-7000 B.P.; Unit 3: 20,000-17,000 B.P.

ally exposes the underlying dentine. The quantity of tooth wear has a direct relationship to mastication, and assuming that the level of mastication has been constant throughout the life of an animal, tooth wear can also be used as an indicator of the time since the tooth erupted. However, a number of factors can influence the results of enamel wear analyses. First, diet has an important role in tooth enamel wear: the consumption of more fibrous plants will result in a different rate of enamel wear than the consumption of more succulent plants. However, the tooth wear data from Buang Merabak should be internally consistent and comparable because they derive from prey captured within the local region, and New Ireland was covered in rainforest that has probably not altered significantly since at least the Last Glacial Maximum (Hope 1996). Second, different teeth can wear at different rates, depending on their morphology and position in the mandible/maxilla: more force is exerted on the anterior teeth than on the posterior teeth, so dentine exposure occurs sequentially from the first to the fourth molar. If the Buang Merabak assemblage contained a greater number of anterior than posterior molars, then the data would be skewed toward scoring for older animals. Figure 3 illustrates the distribution of molars per unit. A chi-square analysis indicated that, while each unit had slightly different values for each of the molars, the difference was not significant $(p \leq 1)$.

Tooth morphology is an important factor in the assessment of tooth wear. When a tooth crown is narrower, the force exerted on the crown during mastication is more concentrated, resulting in an increased rate of wear on a smaller area and consequently more rapid dentine exposure on the tooth. By contrast, when a crown is flatter, the force is dispersed and dentine exposure will appear to occur at a relatively slower rate. The third premolar in $P$. orientalis had a high and pointed crown and would therefore be likely to exhibit dentine exposure on the crown 
Table i. The Relationship between the Toothwear Cohorts Used in the Buang Merabak Cuscus Study and those Proposed by Winter (ig8o) for the Brush-Tailed Possum, Trichosurus Vulpecula (Kerr)

\begin{tabular}{llc}
\hline $\begin{array}{l}\text { WEAR Classes } \\
\text { (THIS ANALysis) }\end{array}$ & $\begin{array}{c}\text { RATE OF WEAR } \\
\text { (THIS ANALYSIS) }\end{array}$ & $\begin{array}{c}\text { WEAR CLASSES } \\
\text { (WINTER I980: } 360 \text { ) }\end{array}$ \\
\hline 1. & None & 1,2 \\
2 & Low & 3 \\
3 & Intermediate & $4-6 \mathrm{a}$ \\
4 & High & $6 \mathrm{~b}, 7$ \\
\hline
\end{tabular}

earlier than on the four molars. The molars, though, have very similarly shaped crowns, suggesting minimal differential wear based on tooth morphology.

Tooth wear studies have not yet been undertaken on extant $P$. orientalis populations, but they have on other taxa within the family Phalangeridae (Winter 1980). The seven wear classes of dentine exposure identified by Winter (1980:360) were simplified for the Buang Merabak analysis into four, in order to reduce observer error and maximize accuracy (Table 1). My Wear Class 1 consisted of teeth without any exposed dentine; teeth in this class may show signs of wear, but not penetrating the enamel. Wear Class 2 consisted of teeth with minimal exposed dentine, commonly on the tops of high cusps. Wear Class 3 consisted of specimens within the range of having small crescents of dentine exposed to having a broad band of dentine exposed across both the lingual and labial cusps. Wear Class 4 consisted of specimens with completely obliterated and dished crowns.

As a result of the combination of cultural and natural formation processes, archaeozoological assemblages are generally highly fragmented, making it difficult to determine accurately the number of animals represented by the material. For this study, each jaw was given one score for tooth wear, irrespective of whether it contained one or all four molars. Potentially this allowed for a single individual animal to be scored more than once, inflating the overall sample size. However, the NISP of teeth per analytical unit indicates that the quantity per molars per analytical unit was not significantly different (as above, Fig. 3).

\section{DISCUSSION}

Unit 3 contained a small number of cranial fragments (though a vast number of post-cranial fragments), making it difficult to extrapolate anything substantive about cuscus predation during the time represented. The quantity of fragments increased dramatically, peaking in Unit 2 before decreasing again in Unit 1 (Fig. 4). The trend might reflect a general increase in cuscus predation, or an increase in deposition at Buang Merabak, or both.

Young animals generally dominated the assemblage. Figure 5 shows the NISP of cuscus dentary fragments per analytical unit per cohort, per 1000 years. It indicates that the quantity of young animals increased from Unit 3 to Unit 2. Taken in consideration with Figure 6, the data suggest that the NISP of animals classified as having low or no dentine exposure increased as the overall NISP of dentary 


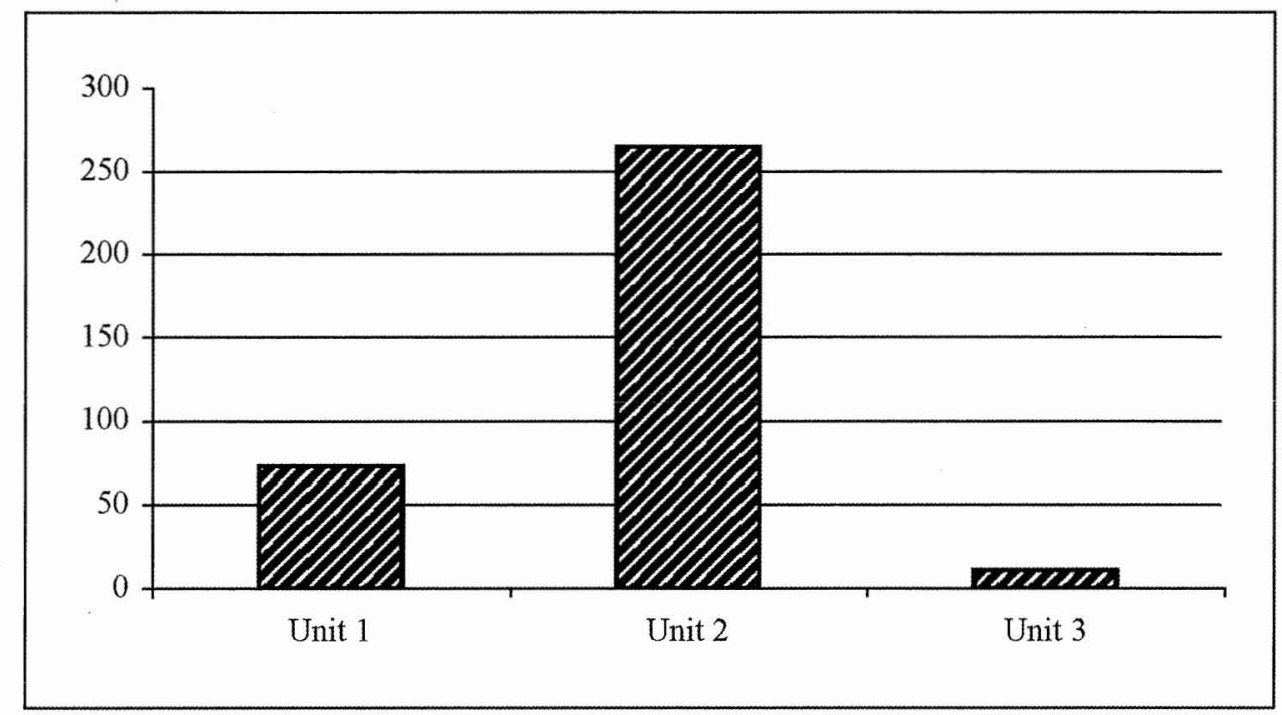

Fig. 4. Buang Merabak cuscus (Phalanger orientalis): dentary NISP (numbers of identifiable fragments) per unit. Unit 1: 1800-3500 B.P.; Unit 2: 12,000-7000 B.P.; Unit 3: 20,000-17,000 B.P.

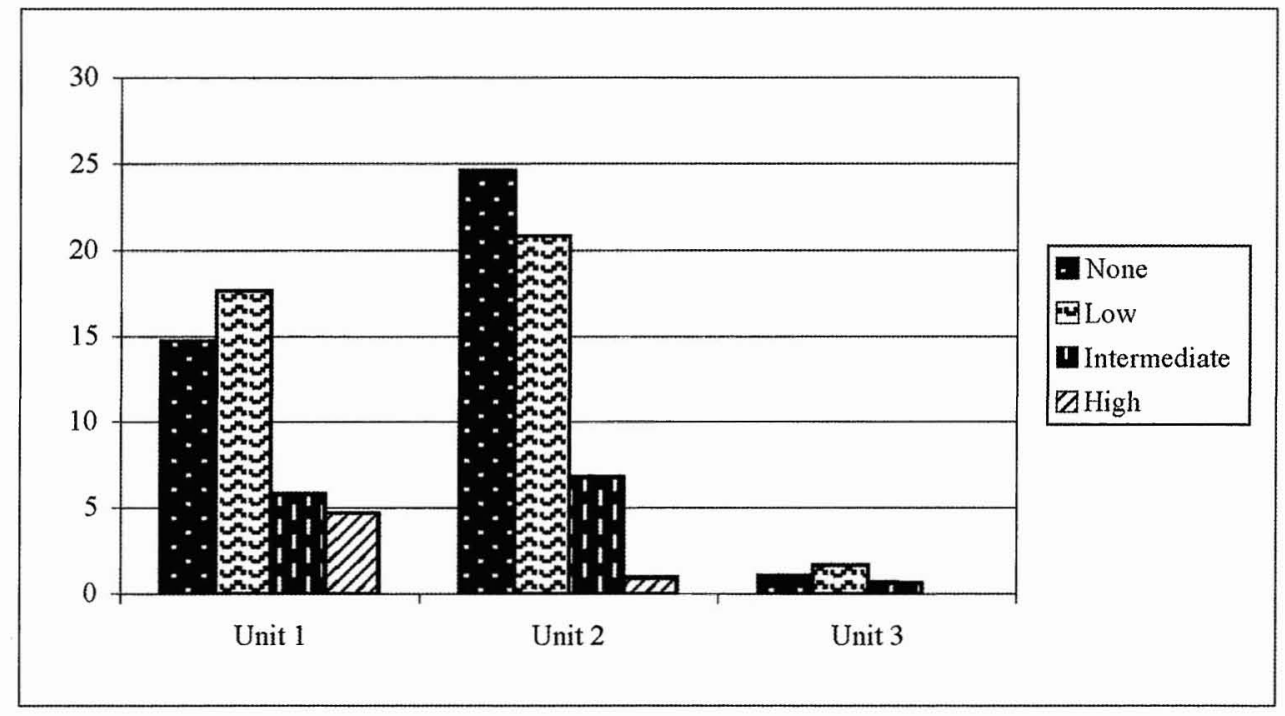

Fig. 5. Buang Merabak cuscus (Phalanger orientalis): rates of wear of dentary NISP (numbers of identifiable fragments) per 1000 years. Unit 1: 1800-3500 B.P.; Unit 2: 12,000-7000 B.P.; Unit 3: $20,000-17,000$ B.P. 


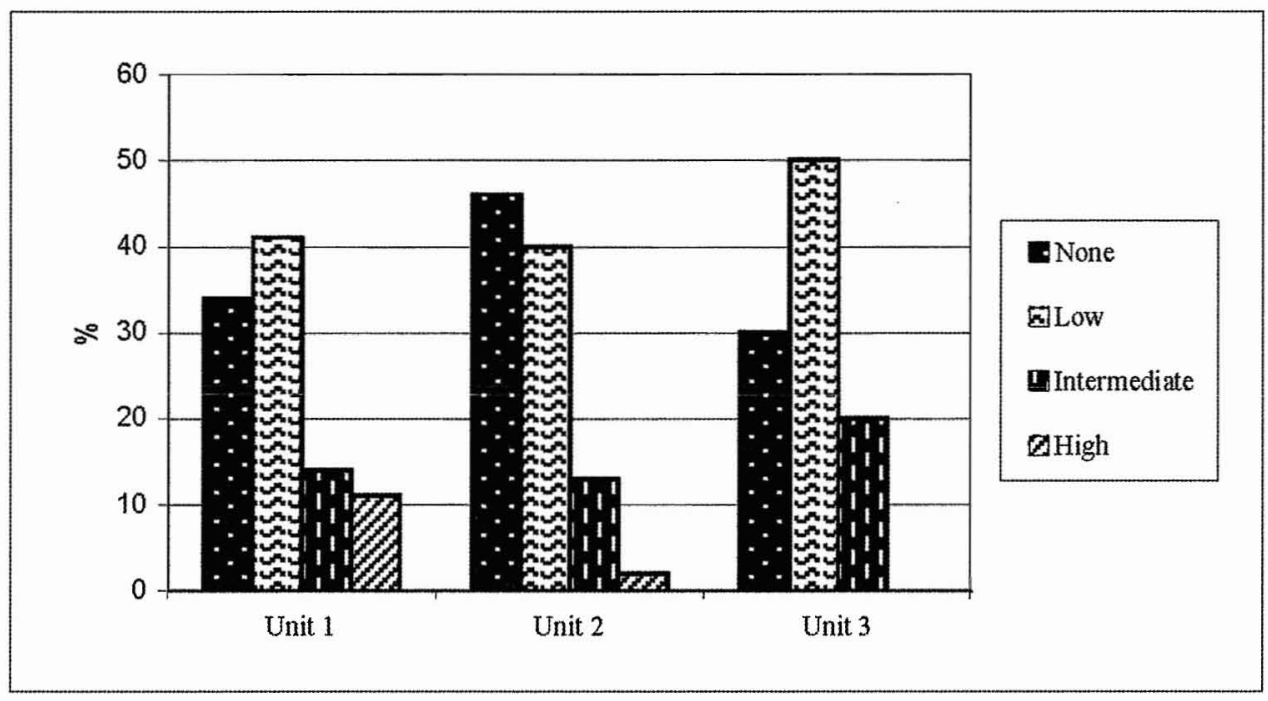

Fig. 6. Buang Merabak cuscus (Phalanger orientalis): percentage of each age cohort per analytical unit, according to rates of wear. Unit 1: 1800-3500 B.P.; Unit 2: 12,000-7000 B.P.; Unit 3: 20,00017,000 B.P.

fragments increased. The trend emphasizes the dominance of the smaller animals in the catch.

The dominance of younger animals may reflect a number of factors. It may be indicative of predator choice, although this would be difficult to substantiate. It may also reflect aspects of New Ireland's ecology (Pasveer 2003). It can be interpreted as indicative of the natural cuscus population that was available to the hunter: in this scenario, the hunter would have been a passive "culler" of the $P$. orientalis population, operating within the constraints of the New Ireland environment, rather than an active hunter making choices regarding preference for prey. From this perspective, the evidence of a cuscus population dominated by younger individuals may represent a population under pressure or expanding.

Alternatively, prey behavior may render certain animals, from within specific age cohorts, more conducive to capture by human hunter. Relatively younger Phalangerids tend to disperse over larger distances relative to mature adults. As young or subadult individuals become independent they tend to range farther in order to find and establish a home range for themselves separate from their mothers. The process of exploration has inherent risks, such as exposure to unknown predators in an unknown microenvironment. It is conceivable that this inexperience put younger individuals at higher risk of capture compared with mature adults and their dependents.

The percentage of specimens with intermediate and high tooth wear in Unit 1 is greater than the percentage in Unit 2. The data may be a reflection of both lo$\mathrm{cal}$ and regional factors. At the local level, the lower NISP of Unit 1 compared with that of Unit 2 could be taken to indicate a reduction in the consumption of 
$P$. orientalis at Buang Merabak. Alternatively, the change might reflect larger-scale regional change associated with the appearance of Lapita pottery and the first evidence of agriculture in New Ireland in the period represented by Unit 1 at Buang Merabak.

The Lapita cultural complex appears in the Bismarck Archipelago at ca. 3500 B.P. and signaled an important shift in subsistence strategies from mobile hunting, gathering, and arboriculture toward sedentary agriculture and pig (Sus scrofa) husbandry (Spriggs 1997). The earliest evidence of occupation at the nearby Lapita site of Lasigi indicated human occupation by 2700 B.P. and settlement activity, including the keeping of pigs, by 2300 B.P. (Golson 1991). Slightly farther afield, pigs are present in the Balof deposits at ca. 3550-3100 B.P. onward (White et al. 1991). In addition to the reduction in cuscus NISP from Unit 2 to Unit 1 (Fig. 4), there was an increase in the proportion of specimens in the "old" (high wear) cohort compared with those in the "intermediate" cohort, and an increase in the proportion of specimens in the old and intermediate cohorts compared with the "low" and "none" cohorts (Fig. 6). The introduction into New Ireland of the Lapita cultural complex, including both agriculture and pig, potentially had a large impact on food acquisition behavior. Access to S. scrofa, both wild and domestic, would have reduced hunting pressure on the cuscus, so while still important, the cuscus would have been reduced to a secondary role in the human diet. Reduced hunting pressure would have provided an opportunity for the cuscus population to expand and as a result increase the availability of larger/older individual animals. The gains in time afforded by agriculture, coupled with the reduced dependence upon cuscus, could also have been a factor in giving people scope to be more selective in their hunting, allowing them to concentrate more on seeking out older and larger individuals.

\section{CONCLUSION}

P. orientalis was first introduced into New Ireland ca. 20,000 years ago (Allen et al. 1989). After its introduction it became the most important island-based protein source in central and southern New Ireland and remained so even after the introduction of the northern pademelon, Thylogale browni. The deposition of cuscus bones at Buang Merabak peaked between ca. 7000 and 3500 years ago, the overall quantity of $P$. orientalis captured thereafter being significantly reduced across all age cohorts. The data also suggest that the prehistoric hunters predominantly captured individuals from the younger age cohorts, perhaps because of the inexperience and vulnerability of young cuscus after leaving the protection of their mothers. The reduction in the quantity of $P$. orientalis captured after 3500 B.P. may reflect changes in subsistence brought about by the introduction of other protein sources associated with the Lapita cultural complex, namely the domestic pig Sus scrofa. The marginal increase in the capture of older individuals at this time may reflect the reduced reliance of people on $P$. orientalis for their protein, the context in which hunters increasingly selected older and presumably larger individual animals. This interpretation of the data implies that hunters at Luang Merabak selected their prey for ease of capture in Units 3 and 2, but for size in Unit 1. It also suggests little direct evidence of resource management. 


\section{ACKNOWLEDGMENTS}

I would like to thank Peter Hiscock, Glenn Summerhayes, Geoff Hope, Matthew Spriggs, Tom Heinsohn (ANU), Ken Aplin (CSIRO), and Kyle Latinis (NUS) for their comments on earlier drafts of this paper. I would also like to thank Tuvu Telexas and Michael Boxos, the traditional owners of Buang Merabak.

\section{NOTE}

1. The radiocarbon dates quoted in this paper are uncalibrated.

\section{REFERENCES CITED}

Allen, Jim, Chris Gosden, and J. Peter White

1989 Human Pleistocene adaptations in the tropical island Pacific: Recent evidence from New Ireland, a greater Australian outlier. Antiquity 63:548-561.

ARCHER, Michael

1984 Australian marsupial radiation, in Vertebrate Zoogeography and Evolution in Australasia: 633808, ed. M. Archer and G. Clayton. Marrickville, Australia: Hesparian Press.

Davidson, Janet, and Foss Leach

2001 The strandlooper concept and economic naivety, in The Archaeology of Lapita Dispersal in Oceania: 115-123, ed. G. R. Clark, A. J. Anderson, and T. Vunidilo. Terra Australia 17. Canberra: Australian National University, Pandanus Press.

FlanNERY, T. F.

1993 Moving animals from place to place, in The First Humans: Human Origins and History to 10,000 BC: 175, ed. G. Burenhult. New York: Harper-Collins Publishers.

FLANNERY, TIM

1995 Mammals of the South-West Pacific and Moluccan Islands. Chatswood: Australian Museum/ Reed Books.

Flannery, Tim, and J. Peter White

1991 Animal translocations: Zoogeography of New Ireland mammals. National Geographic Research and Exploration 7:96-113.

Golson, JaCK

1991 Two sites at Lasigi, New Ireland, in Report of the Lapita Homeland Project: 244-259, ed. J. Allen and C. Gosden. Occasional Papers in Prehistory 20. Canberra: Australian National University, Research School of Pacific Studies, Department of Prehistory.

Gosden, Chris

1995 Arboriculture and agriculture in coastal Papua New Guinea. Antiquity 69:807-817.

GOSDEN, C., AND N. ROBERTSON

1991 Models for Matenkupkum: interpreting a late Pleistocene site from New Ireland, Papua New Guinea, in Report of the Lapita Homeland Project: 20-45, eds. J. Allen and C. Gosden. Occasional Papers in Prehistory 20. Canberra: Australian National University, Research School of Pacific Studies, Department of Prehistory.

Grayson, Donald

2001 The archaeological record of human impacts on animal populations. Journal of World Prehistory 15(1): 1-68.

HeINSOHN, TOM

1998 The Realm of the Cuscus: Animal Translocation and Biological Invasions to the East of Wallace's Line. Ph.D. diss. Australian National University, Canberra.

2000 Predation by the white-breasted sea-eagle Haliaetus leucogaster on phalangerid possums in New Ireland, Papua New Guinea. Emи 100:245-246.

2001 Human influences on vertebrate zoogeography: Animal translocation and biological invasions across and to the east of Wallace's Line, in Faunal and Floral Migrations and Evolution in SE Asia-Australiasia: 153-170, ed. I. Metcalfe, J.M.B. Smith, M. Morwood, and I. Davidson. Lisse: A. A. Balkema. 
2003 Animal translocation: Long-term human influences on the vertebrate zoogeography of Australiasia (natural dispersal versus ethnophoresy). Australian Zoologist 32(3):352-376.

Hope, GeOFF

1996 Quaternary change and historical biogeography of Pacific islands, in The Origin and Evolution of Pacific Island Biotas, New Guinea to Eastern Polynesia: Patterns and Process: 165-190, ed. A. Keast and S. E. Miller. Amsterdam: SPB Publishing.

Latinis, Kyle D.

1996 Hunting the cuscus in western Seram: The role of the phalanger in the subsistence economies of central Maluku. Cakalele $7: 17-32$.

1999 Subsistence System Diversification in Southeast Asia and the Pacific: Where Does Maluku Fit? Ph.D. diss. University of Hawai'i, Honolulu.

2000 The development of subsistence system models for Island Southeast Asia and Near Oceania: The nature and role of arboriculture and arboreal-based economies. World Archaeology 32(1):41-67.

Leavesley, Matthew G.

2004 Trees to the Sky: Prehistoric Hunting in New Ireland, Papua New Guinea. Ph.D. diss. Australian National University, Canberra.

Leavesley, Matthew G., And Jim Allen

1998 Dates, disturbance and artefact distributions: Another analysis of Buang Merabak, a Pleistocene site on New Ireland. Archaeology in Oceania 33:68-82.

Leavesley, Matthew G., Michael I. Bird, L. Keith Fifield, P. A. Hausladen, G. M. Santos, AND M. L. DI TADA

2002 Buang Merabak: Early evidence for human occupation in the Bismarck Archipelago, Papua New Guinea. Australian Archaeology 54 : 55-56.

Marshall, Brendan, and Jim Allen

1991 Excavations at Panakiwuk Cave, New Ireland, in Report of the Lapita Homeland Project: 59-91, ed. J. Allen and C. Gosden. Occasional Papers in Prehistory 20. Canberra: Australian National University, Research School of Pacific Studies, Department of Prehistory.

Pasveer, Juliette $M$.

2003 The Djief Hunters: 26,000 Years of Lowland Rainforest Exploitation on the Bird's Head of Papua, Indonesia. Ph.D. diss. Rijksuniversititeit Groningen, Groningen, Netherlands.

Rosenfeld, ANdréE

1997 Excavation on Buang Merabak, Central New Ireland, in Indo-Pacific Prehistory: The Chang Mai Papers: 213-223, ed. P. Bellwood and D. Tillotson. Bulletin of the Indo-Pacific Prehistory Association 16. Canberra: Australian National University.

Sillitoe, Paul

2003 Managing Animals in New Guinea: Preying the Game in the Highlands. London: Routledge.

Spriggs, Matthew J.

1997 The Island Melanesians. Oxford: Blackwell Publishers.

van Deusen, H. M.

1972 Appendix 1: Some comments on the ecology of some highlands mammals, in OL Tumbuna: Archaeological Excavations in the Eastern Central Highlands, Papua New Guinea: 151152, ed. J. P. White. Terra Australis 2. Canberra: Australian National University, Research School of Pacific Studies, Department of Prehistory.

White, J. Peter, Tim F. Flannery, R. O’Brien, R. V. Hancock, and L. Pavlish

1991 The Balof Shelters, New Ireland, in Report of the Lapita Homeland Project: 46-58, ed. J. Allen and C. Gosden. Occasional Papers in Prehistory 20. Canberra: Australian National University, Research School of Pacific Studies, Department of Prehistory.

WINTER, J. W

1980 Tooth wear as an age index in a population of the brush-tailed possum, Trichosurus vulpecula (Kerr). Australian Wildlife Research $7: 359-363$.

\section{ABSTRACT}

The cuscus, Phalanger orientalis, was probably the most important food source in New Ireland from its introduction 20,000 years ago until the introduction of the 
pig, Sus scrofa, 3500 years ago. Terrestrial, or land-based, fauna were an essential part of the prehistoric diet because they provided both protein and fat, which were often difficult to obtain from marine resources alone. P. orientalis was an important prey species because New Ireland had a relatively low range of prey taxa. Prior to 20,000 B.P., the New Ireland fauna were relatively meager: the potential terrestrial prey taxa for prehistoric hunters included bats, rats, birds, and reptiles. The introduction of the cuscus dramatically increased the number of individual animals and therefore expanded the island-based protein resource available to prehistoric hunters. This paper investigates the nature of the late Pleistocene to Holocene capture of $P$. orientalis based on data from Buang Merabak, a central New Ireland cave site, and investigates whether prehistoric hunters captured $P$. orientalis of a particular age and how this changed over time. Keywords: Pleistocene, hunting strategies, Phalanger orientalis, cuscus, New Ireland Province, Papua New Guinea. 